\title{
Fieldwork, Politics and Ethics
}

\author{
Gábor Vargyas \\ Institute of Ethnology, RCH, Hungarian Academy of Sciences, Budapest
}

\begin{abstract}
In this study, the author reflects on his personal experiences and dilemma, when in 2000 an analyst from the Missing in Action Division of the United States Department of Defence asked him to identify some photos taken during the 1980-s in Vietnam. Although the author refused this request at first, he later realized that he would in fact have to identify himself on the photos and agreed to cooperate. The department wanted to make sure that the person in question was not a lost American officer previously detained in a "re-education camp". The mere fact of this request shocked the author, making him aware of the ideological, political and ethical hazards of field research in Vietnam and the dangers generally inherent in anthropological fieldwork. His article investigates these problems.
\end{abstract}

Keywords: Fieldwork, ethics, politics, Vietnam, secrecy, the anthropology of war

One morning in April of 2000 - nearly a quarter of a century after the end of the Vietnam War and the reunification of Vietnam (July 2, 1976), and more than 10 years after the political transition in Hungary and the completion of my fieldwork in Vietnam (1989) our secretary at the Institute of Ethnology at the Hungarian Academy of Sciences came to me with some unexpected news: "Gábor, some American guy from the Department of Defence in Washington has called you several times and insists on speaking with you!" My blood ran cold. "What on Earth does he want from me, and moreover, how did he find me?!" As an anthropologist who has conducted fieldwork in the mountainous region of Vietnam over a long period of time - something which practically no-one else has since managed to do because of the well-known circumstances - I was well aware of how "sensitive" the territory was from a number of different aspects. (Figure 1) If there was something that I wished to avoid from the very beginning, it was to become embroiled in the international political battles fought by mutually exclusive ideological camps following the Vietnam War, although (I must admit) my special opportunity to do said fieldwork was precisely due to the latter. Even though official diplomatic relations between the USA and the Socialist Republic of Vietnam were already ongoing at the 


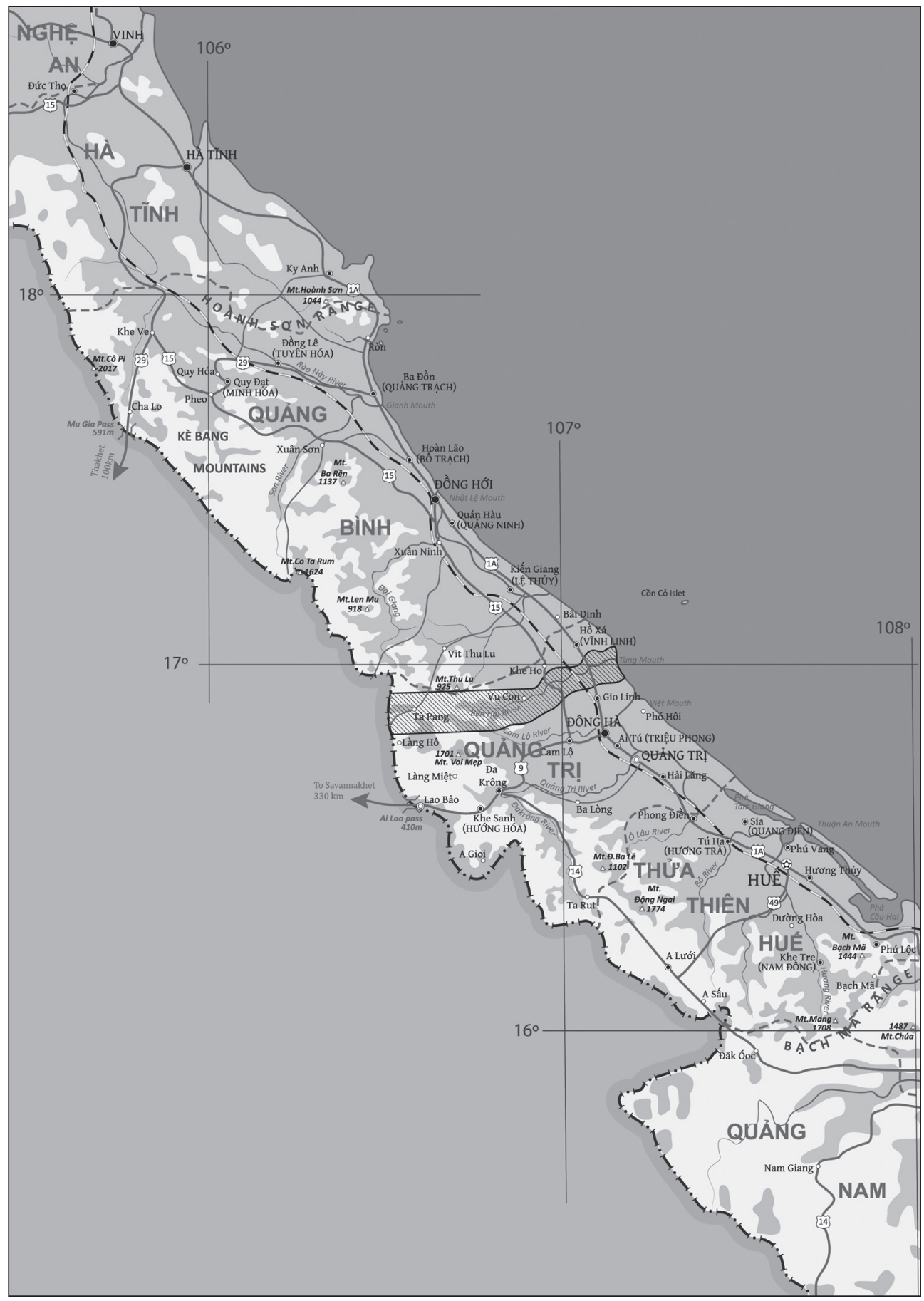

Figure 1. The territory inhabited by the Bru in Central Vietnam. Based on "A Vietnam Tourist Map Northern Section 1:1,500,000, Third Edition, 2002”, produced by Zsolt Horváth, 2016 
time ${ }^{1}$, it was clear to me that any American "news report", especially one involving the military, national security or counter-intelligence, would compromise my reputation in Vietnam and seriously jeopardize further authorization to conduct fieldwork there. It was for this reason that I never sought American grants and also why I rejected a possible American invitation, attempting to develop my contacts primarily with French academia, although in retrospect I am uncertain as to whether my decision was based on the right deductions. After lengthy consideration, I came to the conclusion that the solution - a naive one - was to disown myself. Sooner or later they would grow bored pursuing the matter! Following several increasingly irritated telephone attempts, however, there was a fax waiting for me in my office on April 11 (Appendix 1, Figure 2a). After all, it is quite impossible to remain missing from a state institution for a longer period of time! The writer of the fax - the an analyst - was a certain Mr. Dave Rosenau from the "Current Operations Center" of the "POW/MIA"2 division of the United States Department of Defence. He essentially wanted to persuade me to provide his department with any useful information on alleged American prisoners of war - particularly with regards to my assistance in identifying photos and the individuals and locations they showed. The following excerpt is quoted from the fax:

\begin{abstract}
"Over the past few years, we have received a number of photographs from the area you worked in Vietnam, and we would like your assistance in identifying witnesses, views with regard to the photos, and any other pertinent observations you may have. (...) In particular, we would like to show you several photos and obtain your input with regard to when and where they were taken, who took the photos, and the identities of all individuals shown. We would also be interested in viewing any photographs you took during your time in Southeast Asia."
\end{abstract}

I could no longer avoid answering this request in written form. In my reply, dated April 16 (Appendix 2, Figure 2b), I tried to be positive and helpful, but categorically denied the possibility of any further cooperation. Quote:

\begin{abstract}
“(...) I was very much surprised to hear about Mr. Ho Van Nghe and his suggestion I could be of any help to you. I arrived to the area 10 years after the war had ended and during my one and a half years of fieldwork in the Khe Sanh area from 1985-1989 I never saw, met or heard of any prisoner of war, missing people or camp, let alone the graves of American soldiers. This is why I think, unfortunately, our meeting is unnecessary."
\end{abstract}

Two days later, on April 18, we received another telephone call. By that time, I had become emotionally accustomed to the idea that I would not be able to get rid of this inconvenient contact so easily, whether it was by phone or face to face. I relented and took the telephone receiver. Based on his voice, the person who politely introduced himself on the other end of the line was no doubt a military officer, one whose style suggested that he was used to giving orders and commands. He explained what he had already written and I told him what I had been rehearsing for weeks with an experienced

\footnotetext{
${ }^{1}$ The Socialist Republic of Vietnam and the USA resumed diplomatic relations in 1995 after an interruption of two decades.

${ }^{2} \mathrm{POW}=$ Prisoner of War; MIA = Missing in Action.
} 


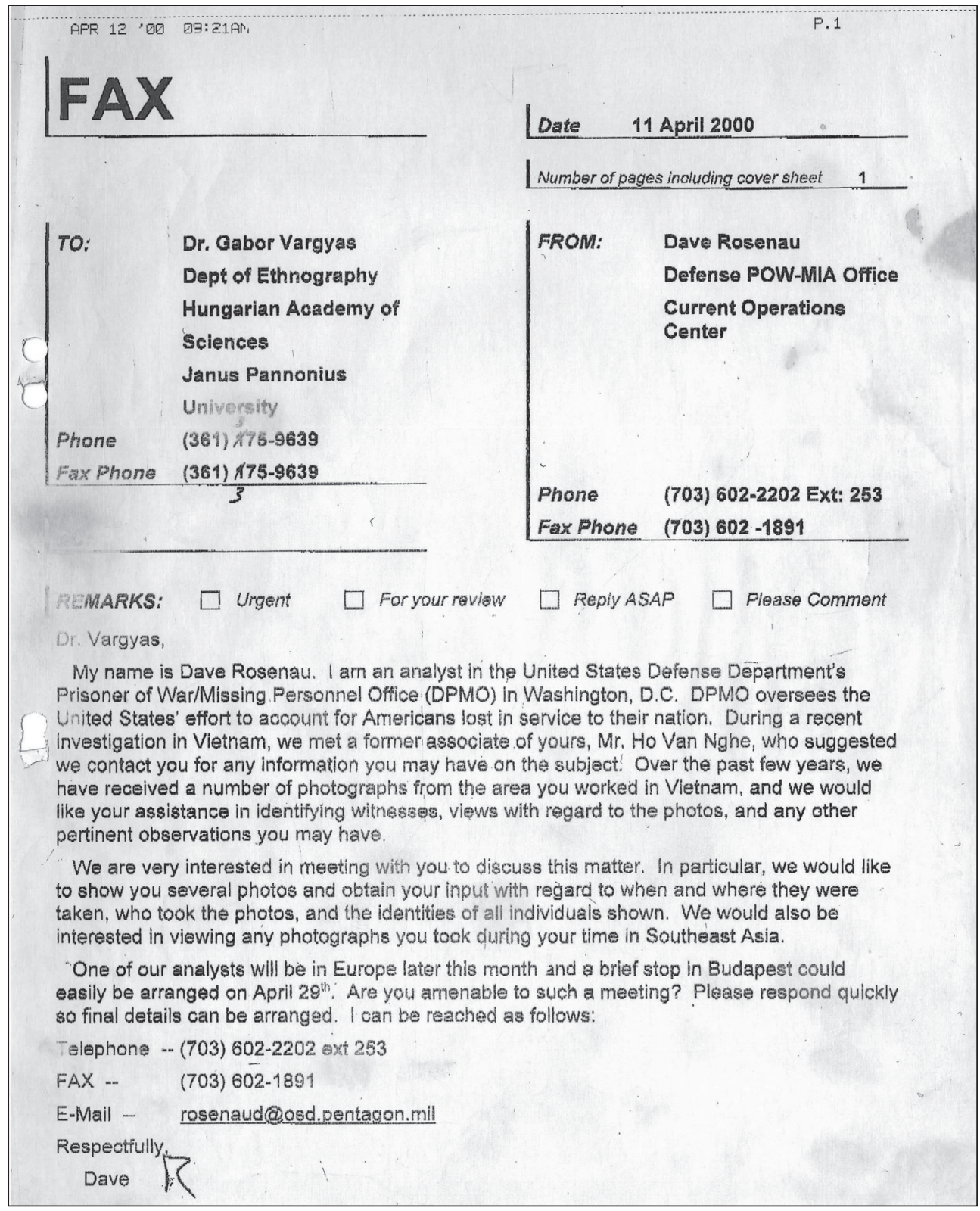

Figure 2a. Fax written to Gábor Vargyas on April 11, 2000 by Dave Rosenau, analyst at the POW/MIA Current Operations Center of the Department of Defence in Washington

French colleague who happened to be visiting Hungary at the time: namely "I'm unable to assist in any way" and "am unwilling to cooperate in any manner" and "especially not in the identification of any Bru individual" (which is what I still thought the issue was at the time). One thing led to another and the conversation had become quite tense when my caller suddenly came to the gist of the matter: "Don't you understand, doctor? We 


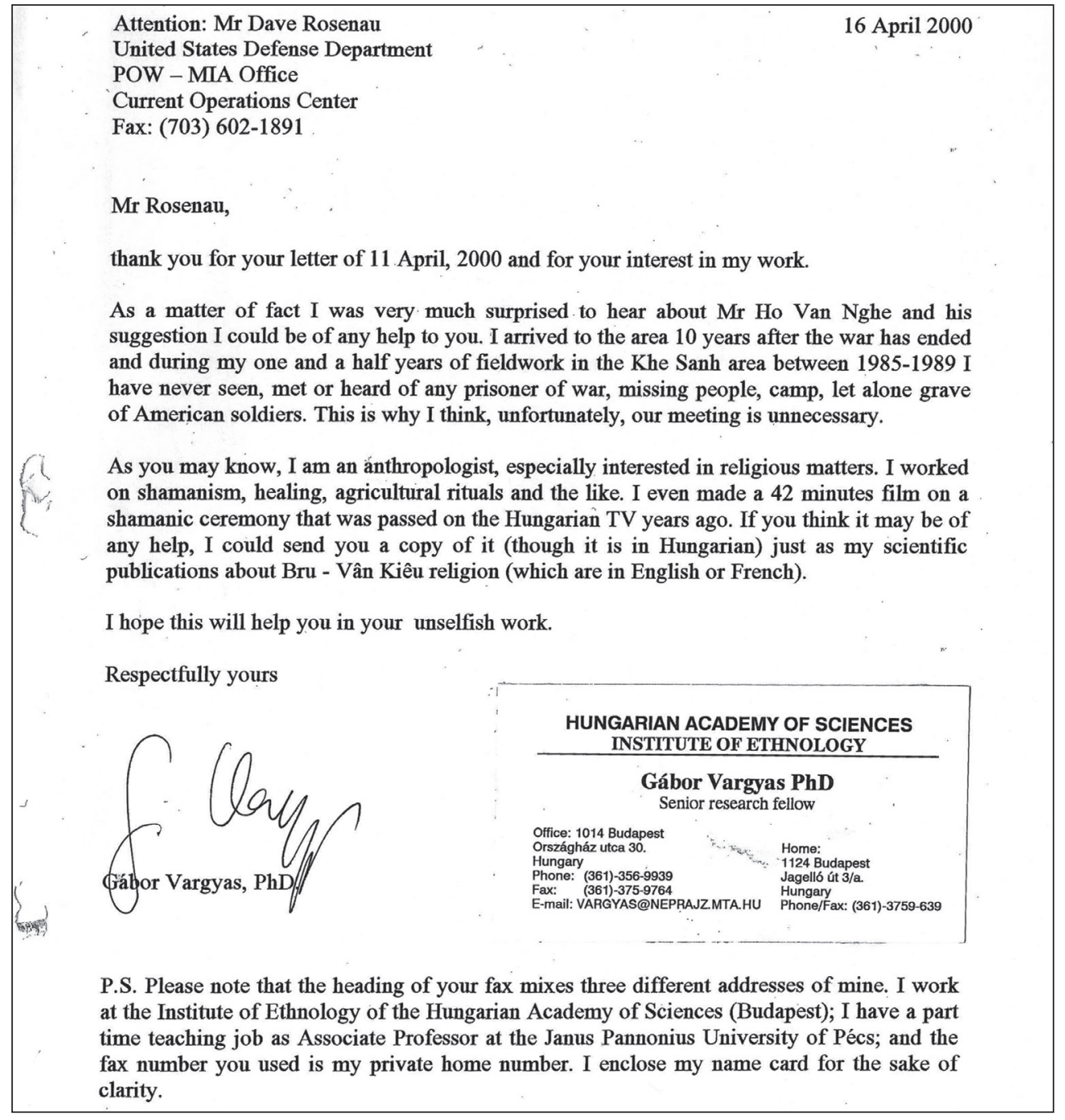

Figure 2b. Gábor Vargyas's reply to Dave Rosenau, dated April 16, 2000

want you to identify yourself." My jaw dropped. "Myself? But how?" He went on: "You are on the photo, and we need you to confirm that the individual in question is in fact you and not an American soldier who "went missing' along the way."

I felt a huge weight slip from my shoulders. "Well, if that's what this is about, no problem!" I received the photos in question within a few minutes via e-mail attachment, and lo and behold! All seven photos showed me, along with my kind Bru friends, my informants, with girls and boys, young and old alike. There I was, the blond, blue-eyed, bearded European man dressed in a military-style camouflage shirt (actually hunting garb), shorts and flip-flops, not so much "concentration camp" fashion, but definitely suited for "jungle-like" conditions! This was how I confirmed that the individual in the 


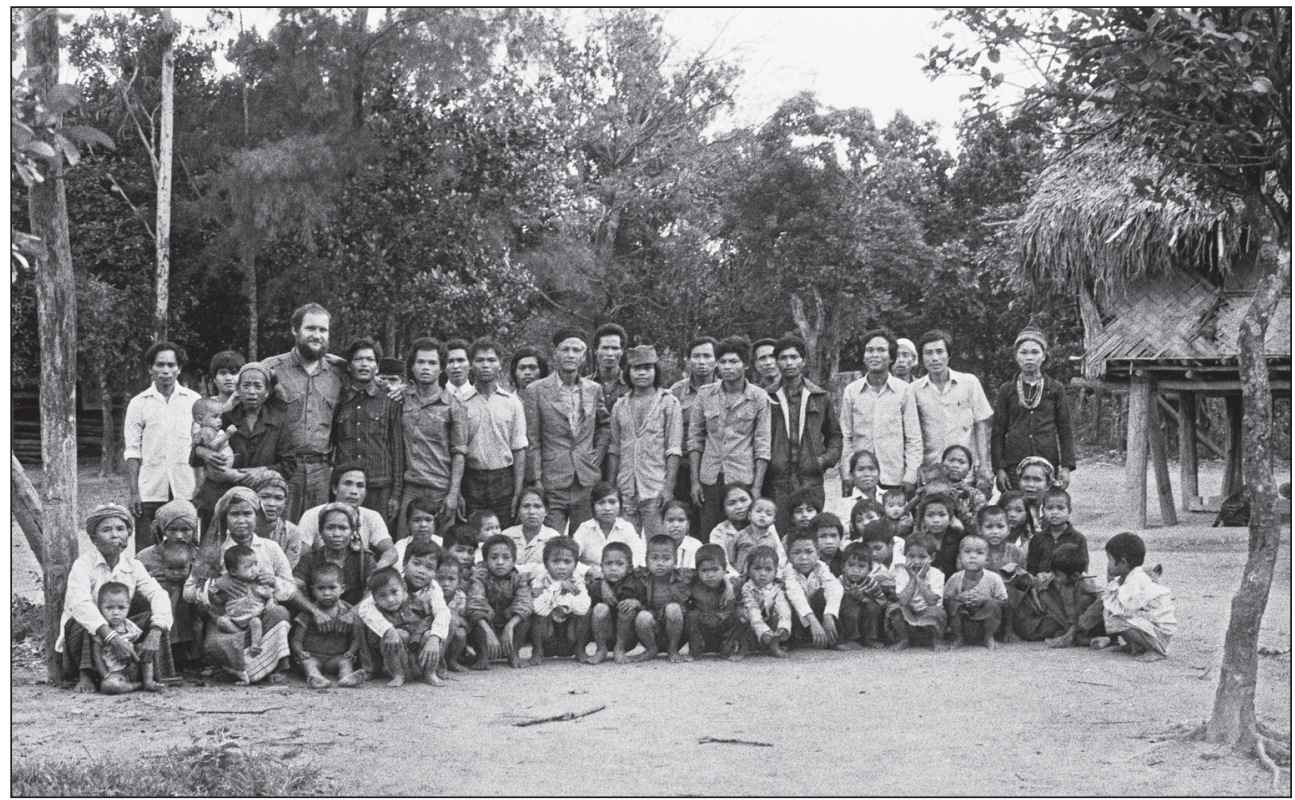

Figure 3. Group photo: Gábor Vargyas and the residents in the village of Xalo. October 5, 1986, Xalo village, photo taken by Vu Dinh Loi (?), using Gábor Vargyas's camera. (Inventory no. MTA BTK NKI: NRK_Ph_47196)

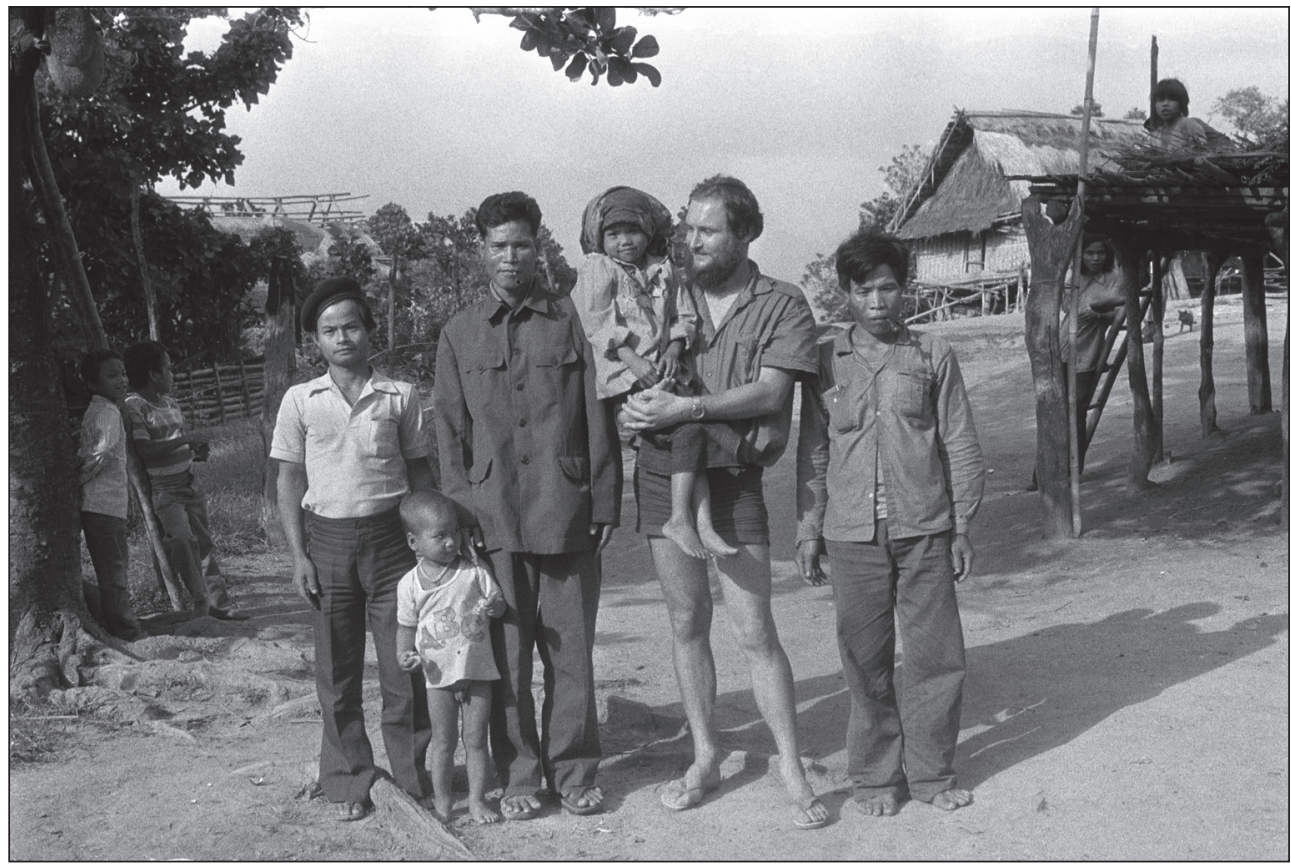

Figure 4. Gábor Vargyas with three men, holding a small child. October 7, 1986, Hoong village, photo taken by Vu Dinh Loi (?), using Gábor Vargyas's camera. (Inventory no. MTA BTK NKI: NRK_Ph_47309) 
Figure 5. Gábor Vargyas with a group of small Bru girls. October 7, 1986, Hoong village, photo taken by Vu Dinh Loi (?), using Gábor Vargyas's camera. (Inventory no. MTA BTK NKI: NRK_Ph_47316)
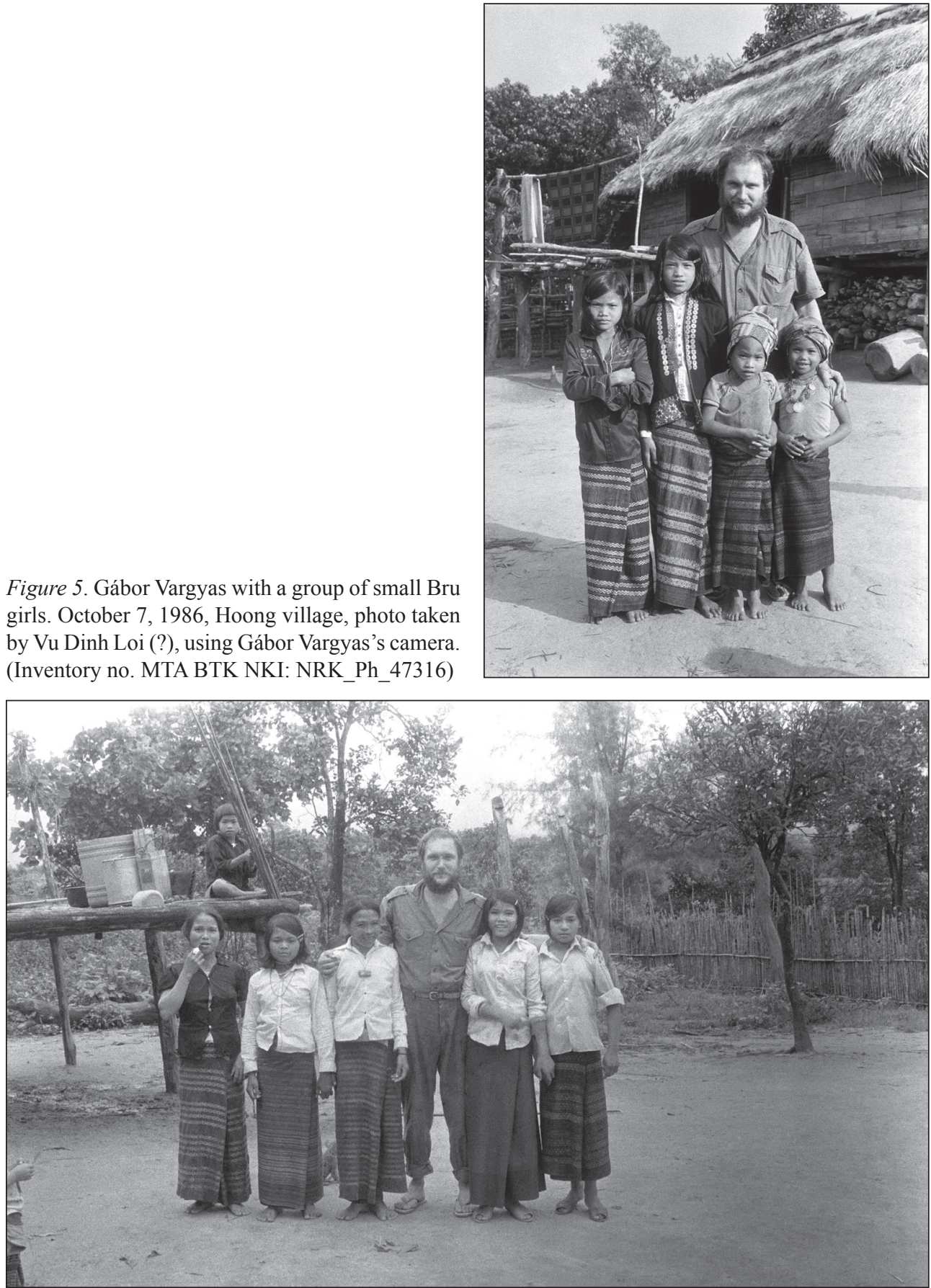

Figure 6. Gábor Vargyas with a group of ta'owai (alternative love song) singers. October 13, 1986, Xalo village, photo taken by Vu Dinh Loi (?), using Gábor Vargyas's camera. (Inventory no. MTA BTK NKI: NRK_Ph_47432) 
photos was not who they were looking for, not an American soldier "missing in action". 3 (Figures 3-6) Following my immediate confirmation via e-mail, the "ad acta" closure of the operation and the file, our correspondence took a 180 degree turn. My conversation partner laughingly thanked me for my cooperation, and when I asked him how they had managed to locate me, he told me in the most natural, self-explanatory tone: "Well, you know, there aren't too many Hungarian doctors named Gábor who worked in Vietnam as employees of the Hungarian Academy of Sciences. You're not so difficult to find!" Then, as if to "comfort me", he explained that they had already managed to find solutions to far more difficult problems, citing a time during the Cold War before the collapse of the Berlin Wall, when an informant of an important information was also successfully located in a prison in East-Berlin!

If I had had any previous doubts, this incident made me understand once and for all that despite our desire to remain in the position of neutral outside observers, as researchers, and especially as social scientists - whether we call ourselves ethnographers or cultural anthropologists - our work has a socio-political-economic context and function with specific corresponding goals. These had been established in definite circumstances and in the interest of definite aims, and even today, we do not operate in an empty space solely for our own purposes. Scientific research is funded (at least in theory) so as to utilize the results, and the latter can also be directly or indirectly used to serve interests that are independent of or even in opposition to the intentions of the researchers themselves. It is not possible to hide from the responsibility; we are not outside of time and space. Moreover, it is precisely because of its socio-political context that our field of scientific research has serious ethical implications.

Let us now focus on the historical context of my story. Due to the lack of time and space, there is no room here for a detailed examination of American and Vietnamese political history in the period following the Vietnam War. The essence of the POW/MIA ${ }^{4}$ issue affecting us can best be summarized on the basis of G. Herring's book, which is now in its fourth edition and is considered to be compulsory reading on the topic. While it can be said that the 1980s saw a softening of relations between the two previously warring factions, which in turn led to normalized contact, the

"POW/MIA issue took on the power and mystique of a religion. In fact, the actual number of MIAs and the percentage of MIAs to casualties were far lower in the Vietnam War than in previous American wars. Most MIAs were air personnel who disappeared under circumstances that made their survival and the subsequent location of their remains difficult if not impossible $(\ldots)^{5}$ The linkage of MIAs to POWs muddled an already complicated issue, suggesting that any of the missing might be prisoners. (...) Between 1975 and 1993 various

\footnotetext{
${ }^{3}$ Unfortunately, I did not download and save the photos sent back to me from America at the time and so am unable to recall which ones were among the approximately 10,000 photos in my collection. Since I have changed my e-mail server since then, I no longer have access to my old account and cannot relocate the photos in question. Nevertheless, it is very likely that the ones shown here were among them.

${ }^{4}$ See: footnote 2

${ }^{5}$ Among the less than 2000 individuals listed as POW/MIAs, approximately half are known to have died under such conditions. See: Herring 2002:362.
} 


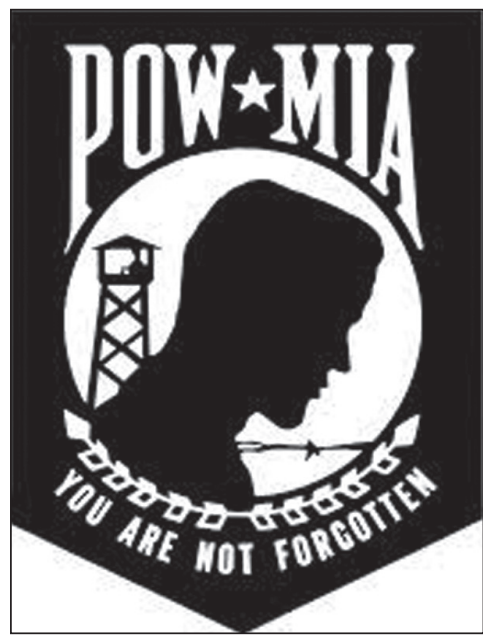

Figure 7. Logo of The National League of Families of American Prisoners and Missing in Southeast Asia; http://www. pow-miafamilies.org/about-the-league/ (accessed September 18, 2016)

congressional and executive groups studied the issue intensively and produced not a shred of evidence that a single American was being held captive in Vietnam. For the United States to demand a full accounting of MIAs from an enemy-especially a victorious enemy with whom it was still technically at war-was quite without precedent in the history of warfare." (HERRING 2002:362)

According to Herring's convincing analysis, the MIA issue was originally put on the agenda by the Nixon administration ${ }^{6}$ in order to successfully sway American public opinion in favour of its interests during the increasingly unpopular Vietnam War. In the long run, this proved to be counter-productive and turned public opinion against the government. As the POW/MIA lobby grew extremely powerful - "spurred by recurrent reports of sightings of live Americans behind the bamboo curtain" - pressure was put on both Hanoi and Washington. The "National League of Families of American Prisoners and Missing in Southeast Asia" was formed and to this day has been the only political lobby in the USA to successfully promote the display of its flag - with its logo depicting a bowed face in black in front of barbed wire and a guard tower with the inscription "You Are Not Forgotten" - on the White House and on other government buildings. (Figure 7) In the meantime, popular, sensationalist Chuck Norris and Rambo films ${ }^{7}$ further reinforced the myth of secretly held American prisoners of war. In 1993, a senate investigative committee reached the conclusion that "charlatans and opportunists' (...) built 'Sa cottage industry out of the despair of bereaved families"" (HERrING 2002:363). Even though Hanoi responded to repeated pressure by occasionally returning the remains of Americans found in the region, 57\% of Americans surveyed in 1993 believed that those deemed "missing in action" were in fact prisoners of war in Indochina!

Herring convincingly goes on to state:

"The myth of abandoned prisoners of war held captive by Indochinese Communists and rescued by American superheroes served urgent post-war needs for redemption, vindication, and reempowerment. It was as though Americans believed that something of themselves had been lost in the war and needed to be rescued. The myth was also used to demonize the Vietnamese and delay ending the war. Responding to the surge of public interest, the Reagan administration after 1982 operated on the assumption that Americans were being held captive, gave the issue the 'highest national priority', and insisted once again that Vietnam provide a full accounting." (HERRING 2002:363)

\footnotetext{
${ }^{6}$ Richard Nixon was president of the USA from 1969-1974.

${ }^{7}$ E.g. "Missing in Action" and "Rambo: First Blood, Part 2" and sequels.
} 
With more than 300,000 of their own "missing in action", Vietnamese were (might have been) rightfully enraged by American demands, but they continuously made concessions due to both domestic and foreign policy issues: on one hand, they wanted to break out from their international isolation and their bonds to the Soviet Union, but they also desired to move forward with the Đổi Móri, the Vietnamese version of perestroika launched in 1986. "They therefore permitted increasing access for Americans to search for MIAs and offered cooperation to try to resolve outstanding issues." (HeRRING 2002:363) In comparison to that of Reagan, the policy of the subsequent Bush administration ${ }^{8}$ was even harsher and led to the development of a so-called "road map" for normalized relations, every step of which was tied to progress on the outstanding MIA issue. By the beginning of Bill Clinton's presidency in 1994, ${ }^{9}$ "American military teams had dug up the Vietnamese countryside, interviewed villagers, and even researched Vietnamese archives in a new and grisly form of body counting." (HeRRING 2002:364) To make a long story short, in the long term the USA used economic tools and other means to win a war which it had militarily lost. "Perhaps never before in the history of warfare had a loser been able to impose such harsh 'peace' terms on the ostensible winner." (HerRING 2002:364)

This is largely what could serve as the political-historical context for my story. As we have seen, the MIA issue had been a part of American politics since the 1970s. The only surprising aspect in all of this is that my own incident took place in April of 2000, when a layman unfamiliar with American domestic policy and world politics would have thought that the affair had ended long ago! At the risk of repeating myself, let me emphasize: by that time, a quarter of a century had passed since the end of the Vietnam War (1975). It was therefore virtually impossible to imagine that any surviving prisoners or MIAs had remained (could have remained) undiscovered after such an intense ideological campaign and such concerted efforts to locate them! Even so, it is in the nature of myths to steadfastly remain, resisting historical change, not to mention reality. This is proven by the fact that the "National League of Families of American Prisoners and Missing in Southeast Asia", established in 1970, is to this day a legally registered organization (!) with a currently operating website that states the following: "The League's sole mission is to obtain the release of all prisoners, the fullest possible accounting for the missing and repatriation of all recoverable remains of those who died serving our nation during the Vietnam War." [Italics in the original, G.V.] ${ }^{10}$ Whether it was myth or reality, in April of 2000 the U.S. Department of Defence continued to keep the issue on its agenda, perhaps in fear of the still influential POW/MIA lobby - and I would even go so far as to assume that it continues to do so now!

At this point, I would also like to reflect on a much earlier, yet relevant memory! In late April of 1988, on the way to the Bru between Hue and Khe Sanh, we were riding

\footnotetext{
${ }^{8}$ Ronald Reagan was president of the USA from 1981-1989, followed by George H. W. Bush Sr. from 1989-1993.

${ }^{9}$ Bill Clinton was president of the USA from 1993-2001.

${ }^{10} \mathrm{http}$ //www.pow-miafamilies.org/about-the-league/ (accessed September 18, 2016)
} 
in an old, Soviet-made Vietnamese Communist Party jeep, along with my wife, ${ }^{11}$ an East-German expert and a few Vietnamese party cadres. We had stopped at an overlook on a mountain pass and were just preparing to take photographs when a black, airconditioned luxury car pulled up beside us. The chauffeur got out and opened the rear door. The first to step out was an incredibly delicate and elegantly dressed Vietnamese woman in traditional Vietnamese female garb (áo dài) ${ }^{12}$ and modern, high-heeled shoes. She was followed by a flagrantly handsome, tall, athletic, blond, blue-eyed gentleman wearing a sporty suit - who later turned out to be an American senator. One could not have asked for a greater contrast: we were dirty, sweaty and stinky from our long ride in the open jeep, wearing whatever we had - in Eastern-European, or rather raggedy Vietnamese style; torn sandals, stained shirts, military attire. ${ }^{13}$ Last, but by all means least, and thankfully for the last time, was the East-German expert, dressed in some kind of overalls and a jacket. Introductions were made - I can still remember the scent of perfume surrounding the woman, who was the interpreter - and conversation ensued. As a member of a congressional investigation committee, the distinguished senator had just arrived from Khe Sanh in search of POW/MIAs. As soon as he found out who I was, what I was doing, who I was working with and where, his gaze brightened; I was his man! He took me aside with an air of confidentiality and asked whether I had seen or heard of such individuals or camps. After all, who could provide him with information, if not me? I had no choice but to disillusion him as well. Not only did I have no knowledge of such things, but I did not believe they existed either, and I also told him why. $\mathrm{He}$ accepted this and we engaged in friendly conversation for a few more minutes. His attempts to approach my East-German colleague proved to be more challenging. The man had obviously been thoroughly indoctrinated, and he seemed thrilled to be facing a high-ranking representative of rotting American capitalism. He lectured the American on class struggle and the ideological superiority of the GDR in comparison to the USA. (He emphasized several times that he was from East-Germany, i.e. the German Democratic Republic.) Thus, after a brief give and take battle, the senator bid his farewells. He warmly shook my hand, gave me a friendly pat on the back and threw a sarcastic comment at the East-German. I will never forget how he ended his sentence by placing a separate and exaggerated emphasis on the magic term German Democratic Republic.

\footnotetext{
${ }^{11}$ When I left for my third fieldwork trip on December 12, 1987, I still had no idea how long I would be staying in Vietnam. I was trying to extend the agreed annual two-month academic allowance by combining two months at the end of 1987 and two months at the beginning of 1988 - with no knowledge of whether the host party in Vietnam would agree. In addition, I had approached the then secretary-general of the Hungarian Academy of Sciences, sociologist Kálmán Kulcsár, prior to my departure in order to obtain separate funding from the budget at his personal disposal that would allow me to spend at least one year in the field in accordance with international requirements. When I find out in March 1988 that I had received 1000 USD additional funding as a result, my wife came after me with close to a year's worth of film rolls, recording tape and dry batteries necessary for the fieldwork. This enabled her - among other things - to spend two days and one night in Khe Sanh and in the Bru village of Labũiq.

${ }^{12}$ Such clothing is generally worn on special occasions, at receptions, exhibitions etc.

${ }^{13}$ Due to the lack of clothing in Vietnam at the time, it was still common for civilians (mainly men) to wear military garb.
} 
The only reason that I have recalled this by now forgotten episode is to point out that I have already had to unexpectedly face the MIA issue twice during my lifetime within the space of 12 years, which gives an obvious indication of the war-burdened, hysterical and ideologically charged atmosphere I had to work in then and still do today. I have emphasized the MIA issue here as a single projection of the ideological-political circumstances dictating the framework of my field research, one that has obvious ethical implications for me, but it is also obvious that this constitutes only the tip of the iceberg. Even today, there are many things that would be unfortunate to report or write about in the public sphere.

Before I go on to address another ethical issue that arose in connection with MIAs, there is one detail from the previous story which remains to be clarified. How did the Current Operations Center obtain the photographs of me? Who was the man who went by the Vietnamese name Ho Van Nghe, or the Bru version, mporaq Nghe, who originally provided the photos to the Americans, and how did he obtain them? The explanation is simple. In the course of my third trip to Vietnam in $1987-88^{14} \mathrm{I}$ became acquainted with a Bru man serving as a policeman in the local public administration of Khe Sanh. This was a rare phenomenon in itself. The number of nationalities working as employees in the Vietnamese state apparatus, especially in the politically sensitive mountain regions, was minimal and was even rarer in law enforcement organizations. Moreover, mporaq Nghe was extremely intelligent and was also exceptionally skilled at explaining abstract things, which was not frequent among Bru either. During our discussions, he explained that he would soon be travelling to East-Berlin for a longer period of time, acting as a police "escort" for a group of female Vietnamese weavers. Although I had strong doubts about this, I gave him my home address and contact information, and we agreed that he would notify me when he had arrived. To my great surprise, in the spring of 1989 he contacted me to say that he had in fact arrived! In accordance with our prior agreement, I wrote a letter stamped and signed by the director of the Institute of Ethnology and sent it to the indicated East-German manufacturing unit (or perhaps to the political leader of the Vietnamese weavers (?) - unfortunately, I can no longer remember). In my letter, I described the scientific importance of mpo'aq Nghe's visit to Hungary and the significance of the occasion, requesting that he be provided with one month's paid leave. Unbelievably - but that is how things still worked at the time! - mporaq Nghe arrived in Budapest for one month's paid leave in May/June 1989. He lived in our flat, ate with my family and we worked at translating Bru folklore texts I had recorded earlier. ${ }^{15}$ (Figure 8) At the time, I was busy preparing for the $9^{\text {th }}$ international conference organized by the International Society for Folk Narrative Research in Budapest ${ }^{16}$, where I was to give a lecture on genres in Bru folklore. Mporaq Nghe also took part in the conference as a listener, and on June 16, 1989 we both "skipped" the conference to attend the reburial ceremony of Imre Nagy and other martyrs of the 1956 revolution. I still remember

\footnotetext{
${ }^{14}$ December 12, 1987 - early October 1988

${ }^{15}$ By his own account, this is where Lajos Boglár, an Americanist colleague of mine, had the idea of inviting a Wayana Indian shaman named Wayaman to Hungary from French Guiana in July 1993 following his work with András Kepes, a well known Hungarian TV reporter on a TV film there. The shaman stayed with Lajos Boglár for three months and made several public appearances in Budapest.

${ }^{16}$ The ISFNR conference in Budapest took place from June 14-17, 1989.
} 


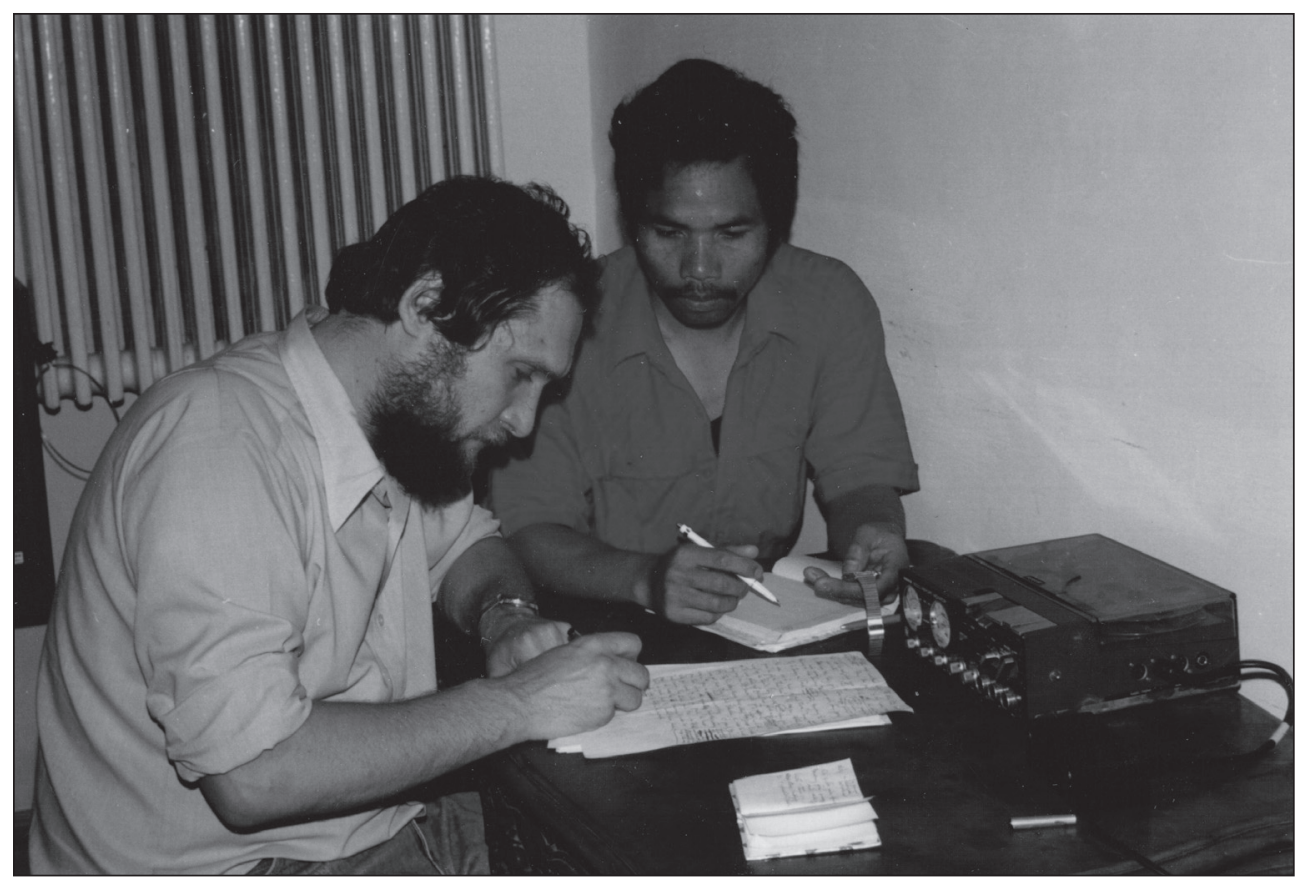

Figure 8. Ho Van Nghe (Bru version: mpo'aq Nghe), with Gábor Vargyas while translating Bru folklore texts in preparation for the ISFNR conference in Budapest. Budapest, May-June 1989, photographer unknown

the curious feeling I had when the main speaker asked the approximately $150,000^{17}$ attendees to hold one another's hands in a show of solidarity and my Bru friend mpo'aq Nghe grabbed my right hand! To paraphrase Marx, "a spectre was haunting Europe the spectre of the worldwide downfall of communism" - and at the reinternment of a martyred communist politician, a symbolic projection of the collapse of the communist system, a Bru highlander from communist-friendly Vietnam who had arrived in Budapest on a side-trip from East-Berlin was holding the hand of a Hungarian anthropologist!

After one month had passed, mpóaq Nghe returned to East-Berlin and shortly thereafter I left for my last field trip (September 2, 1989 - December 23, 1989). In the meantime, the rapid and stormy events taking place in world politics (the symbolic cutting of barbedwire fence, the release of East-German refugees, the "velvet revolution" in Prague, the collapse of the Berlin Wall, the execution of Ceausescu and the disintegration of the Soviet Union) swept us away from one another. Except for my occasional participation at conferences in Vietnam, I was only able to conduct fieldwork among the Bru again in 2007, and not in the original location near Khe Sanh in Quang Tri province, but some 700 kilometres to the south among a group in Dac Lac province who had been resettled during wartime.

${ }^{17}$ Contemporary sources estimated the number of attendees to be from 150-250,000. See: http://barankovics.hu/cikk/idoszeru/25-eve-volt-nagy-imre-es-martirtarsainak-ujratemetese. (accessed September 18, 2016) 


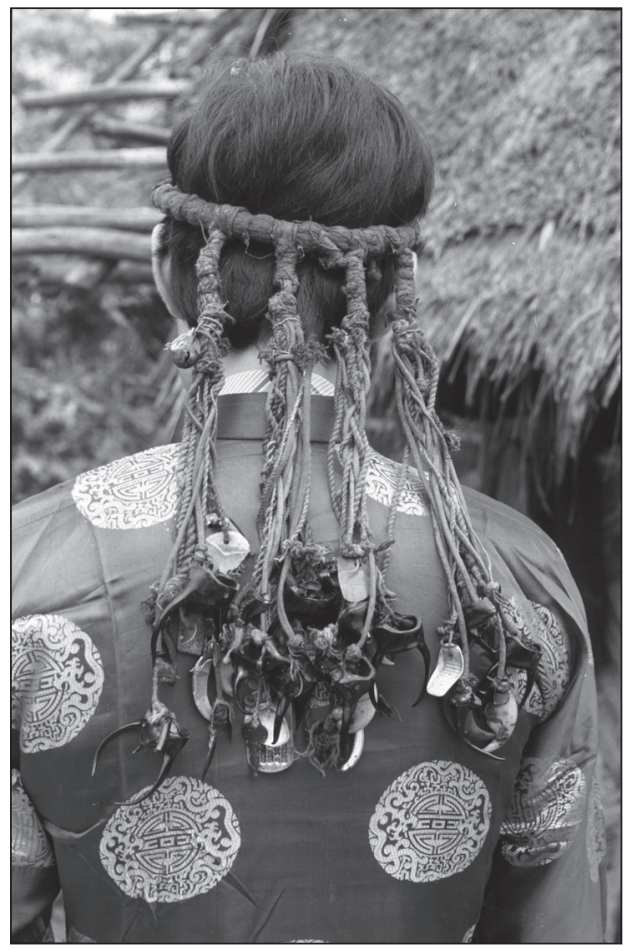

Figure 9. Bru shamanic headdress with the dogtag of an American soldier. Xalo village, photo by Gábor Vargyas, October 15, 1986
However, like many of my Bru acquaintances, friends and informants, mporaq Nghe received numerous photographs from me, and not just in Budapest, but earlier as well. It was my colleague, Lajos Boglár, mentioned above, who had recommended this tried and true anthropological fieldwork method during our friendly tete-a-tete chats prior to the research. ${ }^{18}$ This basically entailed taking advantage of my multiple brief trips to the region in question, which I experienced as a drawback at first. It turned out that gifts brought with me upon my return, especially photographs taken on trips the previous year, went a long way towards strengthening friendships. I took Boglár's advice and returned to the fieldwork site each year with several hundred black and white photos (and sometimes colored ones). These were then exchanged and wandered from hand to hand, among other things depending on how many people were on them, who I had given them to beforehand and how many, and mainly on who had passed them on to who and who wanted to give them to which relative. The photos

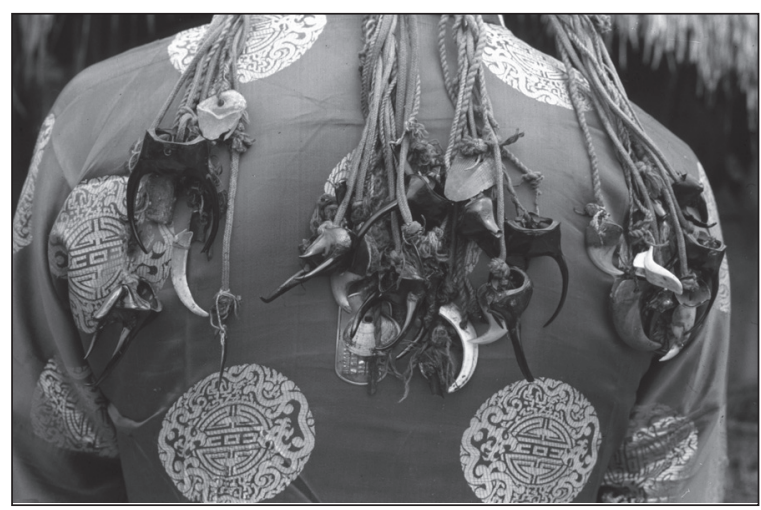

Figure 10. Detail of the Bru shamanic headdress. Xalo village, photo by Gábor Vargyas, October 15, 1986

${ }^{18}$ Before my first fieldwork in Vietnam in 1985, I had the privilege of having several private discussions with Lajos Boglár, who at the time was the only Hungarian anthropologist to have conducted long term fieldwork based on participant observation outside of Europe. At my request, we met on several occasions, during which he prepared me for the difficulties and problems that I might encounter in the course of my own fieldwork. 
that people were especially fond of were the ones that showed not only the Bru themselves, but the ones taken together with me! After all, it was a special memory for them to be photographed with a "white" man, which has not happened with great frequency since then either. To sum up: many photographs showing me or me together with someone else were passed around among the Bru at the time, and they are most likely still being passed around. This means that after 1994 - when "American military teams dug up the Vietnamese countryside, interviewed villagers, and even researched Vietnamese archives in a new and grisly form of body counting". (HERring 2002:364) - it was probably not very difficult for delegates from the Department of Defence (or any other organization for that matter) to collect a few of these photos (seven!) while walking among the Bru. This might have been the way that the pictures of me ended up in Washington. It is also why I believe that unlike many other Vietnamese guest workers who remained in the West following the collapse of the Berlin Wall, mporaq Nghe in all likelihood

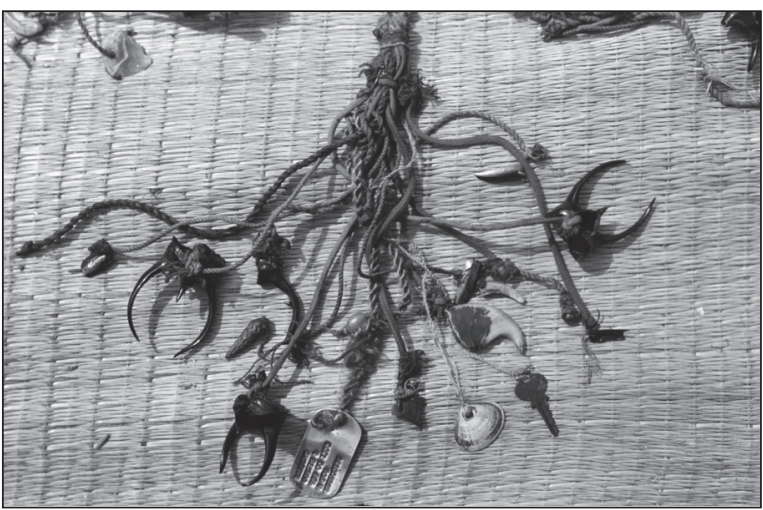

Figure 11. The Bru shamanic headdress spread out: the dogtag is clearly visible among the attributes. Xalo village, photo by Gábor Vargyas, October 15, 1986

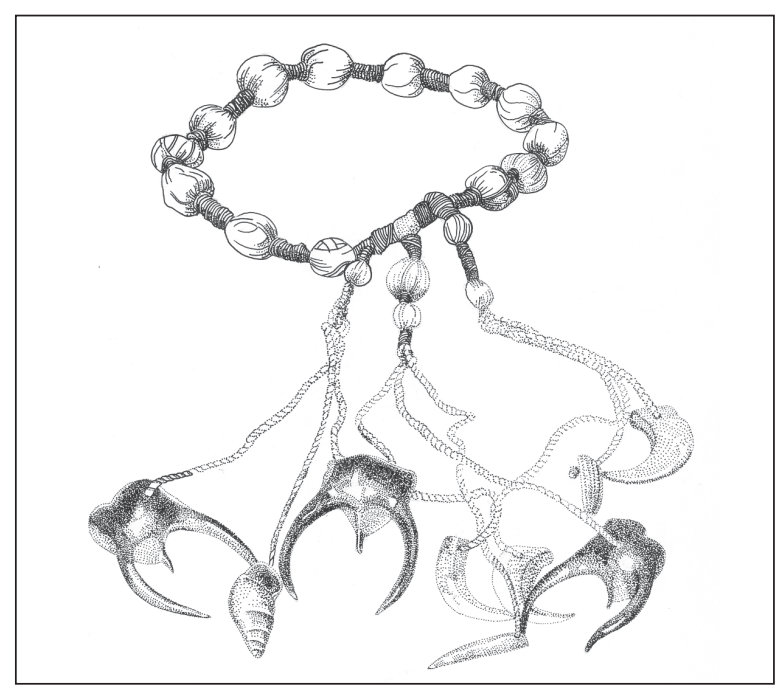

Figure 12. Drawing of the shamanic headdress prepared for Gábor Vargyas. Property of Gábor Vargyas returned to Vietnam - unless (just for the sake of a joke) the American authorities obtained them from him in an EastGerman prison! ${ }^{19}$

In conclusion, allow me to address a specific ethical dilemma arising from the MIA issue. In 2004, I wrote a long article (so far only in Hungarian) about Bru shamanic headdresses and their symbolic "attributes", including a detailed analysis of beliefs and myths related to them (VARGYAs 2004). These attributes can be a wide variety of natural

${ }^{19}$ In March 2019, just before the publication of the English version of my paper, I managed to return to Khe Sanh for a short time and we had the pleasure to meet again, after a thirty years long absence. 
objects: the prothoraxes of stag-beetles, tiger or bear claws, the tusks of domestic pigs or wild boar, the eye-teeth of certain deer and other animals e.g. wild dogs, the scales of the pangolin, the colored (green) elythrons of various beetles of the Buprestidae family, shells, terrestrial and sea snails, along with man-made objects, such as magnifying glasses, keys, rattles, glass beads, cast metal plates with magical inscriptions and - here is the ethical issue - the dog tags of an American soldier who was most likely "missing in action"! (Figures 9-12)

We know that

" $D$ Dog tag' is an informal but common term for the identification tags worn by military personnel. (Figure 13) The tags are primarily used for the identification of dead and wounded soldiers; they have personal information about the soldiers [i.e. name, social-security number, religious affiliation, G.V.] and convey essential basic medical information, such as blood type and history of inoculations. (...) Dog tags are usually fabricated from a corrosion-resistant metal. They commonly contain two copies of the information, either in the form of a single tag that can be broken in half or two identical tags on the same chain. This duplication allows one tag (or half-tag) to be collected from a soldier's body for notification and the second to remain with the corpse when battle conditions prevent it from being immediately recovered. The term 'dog tags' arose because of their resemblance to animal registration tags." ${ }^{20}$

Following the analysis of these attributes, and specifically in connection with the dog tags, I came to the conclusion that

"however grotesque or even blasphemous the thought may be, the logic applied to this object is the same as the one that applies to all of the other objects mentioned above: the 'essence' of the American soldier, his life and his death, are represented by the personal data [...] contained on that simple aluminium plate - because access to it can only be gained through the individual's death. And if we already have a piece of this terrifying thing in our possession, then this not only signifies victory over it, but also means that we have brought that certain 'thing' over to our side." (VARGYAS 2004:427.)

Naturally, I have not provided the data on the dog $\operatorname{tag}^{21}$ for reasons of personal privacy - although it occurred to me in retrospect that despite the poor quality of the printing,

${ }^{20}$ See "dog tag" https://en.wikipedia.org/wiki/Dog_tag accessed March 10, 2018, See also: Cucolo 2013.

${ }^{21}$ Based on the Wikipedia entry for "dog-tag", I could not decide which branch of the armed forces the soldier in question belonged to. The data he carried largely corresponded to those given for the U.S. Air Force (Format 2: Last name, First name and middle initial, Social Security number, followed by "AF" indicating branch of service, Blood Group, Religion), but the "AF" inscription is missing and the article makes no mention of the 3-2-4 format of the social security number. Data given for the U.S. Marine Corps (Last name, First and middle initials and suffix; blood group, Social Security number with three/two/four format as follows: 12345 6789, Branch ("USMC"); Gas mask size (S - small, $\mathrm{M}$ - medium, L - large), Religious preference, or medical allergy if red medical tag) are listed in a different order, and the data regarding the size of the gas-mask and possible allergies is missing. At the same time, the social security number does indeed follow the 3-2-4 format mentioned here. 
and even without magnification or high-tech military equipment, the data can probably be discerned with the naked eye. For me, the ethical dilemma was not whether the data could be published or not. I was and still remain certain that it cannot. The issue for me was whether I had a right to let the world know that I was in the possession of such "delicate" data.

The problem is more complicated, however! Dog tags, as we have seen, were produced in duplicate. At the same time, several sources have indicated that it was common among soldiers, at least among close friends, to give half-tags to each other as gifts. In the

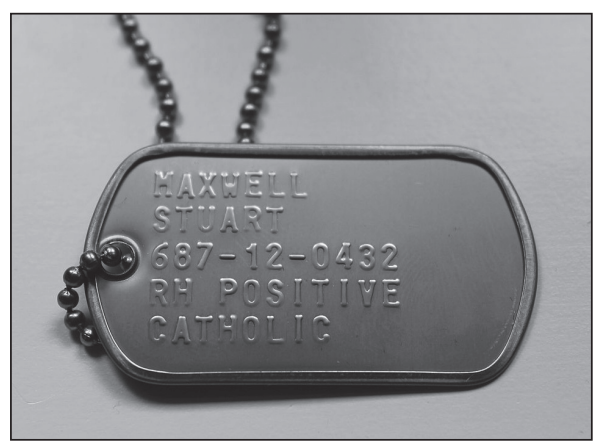

Figure 13. American dog-tag. See https://en. wikipedia.org/wiki/Dog_tag. (accessed March 10, 2018) tapes I recorded about his life story, my key source and my favourite Bru friend, who fought for several years in the service of the Americans, mentioned on more than one occasion that tags were exchanged as a gesture of friendship. He also had two in his possession, but deliberately "lost" them after the war and could only remember the Bru nicknames for the individuals in question. On one hand - at least according to the owner of the shamanic headdress - this particular dog tag was taken from a dead American soldier ... but I cannot decide how reliable this information is either. Firstly, I definitely remember his sardonic smile when he told me that the tag in question had been taken from "a large white man like yourself"...! On the other hand, he claimed to be the third owner of the headdress as part of a hereditary chain, and I was unable to clarify who had actually placed the tag on the shamanic headdress. ${ }^{22}$ It is quite possible that he had only heard about the case by word of mouth, although inheritance among close relatives makes word of mouth all the more plausible.

Whatever the case may be, I have never published the data in question and will probably never do so. ${ }^{23}$ The issue is not that but whether it was and continues to be appropriate for me to keep this data secret from the American authorities. Should I not have long ago reported it to them so that the relatives of the deceased could finally be notified that he was in fact not "missing in action" and possibly imprisoned to this day, but a soldier who actually lost his life in combat? As I have already mentioned, at the beginning of my fieldwork I took great pains to ensure that I would not be "news" to any kind of American government agency or military authority. In the meantime, however, everything around us changed: more than forty years have passed since the end of the Vietnam War; ${ }^{24}$ and in 1995, after a twenty-year interval, America and Vietnam cast a veil over the past and resumed diplomatic relations in parallel with an easement that involved American military teams "digging up the Vietnamese countryside in search

${ }^{22}$ This collecting situation took place at the start of my fieldwork in 1986, when my speaking skills in the Bru language were still weak.

${ }^{23}$ I would make an exception if I received an official request from the aforementioned POW/MIA division of the Defence Department in Washington following publication of this article.

${ }^{24}$ With regards to this, I should mention that in democratic states the time interval for the disclosure of confidential documents is 25 years! 
of MIAs". The annual "Bilateral Human Rights Dialogue" between the two states was launched in 2006, and in 2007 congress voted for the principle of "Permanent Normal Trade Relations" regarding Vietnam. ${ }^{25}$ In light of the historical context I have described above, I am also sure now that my making contact with the United States would no longer cause any problems with Vietnamese authorities. Furthermore, the relatives of the deceased would most likely be happy to finally have their 40 years of doubt ended!

Even so, one last problem remains. At some point, I imagined myself in the shoes of the dead American soldier's family when they found out through my report and the accompanying photograph that their child's/father's/husband's "personal data tag" - let us avoid calling it a dog tag now - currently adorns the headdress of a shaman from a Vietnamese hill tribe! I am not certain that this would be the best way to end the story. Perhaps the myth is more comforting: he is still alive somewhere, and who knows, maybe one day he will come home to us!

\section{REFERENCES CITED}

Cucolo, Ginger

2013 Dog Tags: The History, Personal Stories, Cultural Impact, and Future of Military Identification. Gillingham: Allen House Publishing.

HERRING, George C.

$2002^{4}$ America's Longest War. The United States and Vietnam, 1950-1975. BostonBurr Ridge, Ill.-Dubuqe, IA-Madison, WI-New York-San Francisco-St. Louis-Bangkok-Bogotá-Caracas-Kuala Lumpur-Lisbon-London-MadridMexico City-Milan-Montreal-New Delhi-Santiago-Seoul-SingaporeSydney-Taipei-Toronto: McGraw-Hill Higher Education.

VARGYAS, Gábor

2004 A brú sámánfejdísz [The Bru Shamanic Headdress]. In AndRÁSfalvy, Bertalan - Doмокоs, Mária - Nagy, Ilona (eds.) Az idö rostájában. Tanulmányok Vargyas Lajos 90. születésnapjára. I-III. II, 395-436. Budapest: L'Harmattan.

${ }^{25}$ The official name for this until 1998 was "Most Favoured Nation Clause". 
APPENDICES

\section{Document 1: Letter addressed to Gábor Vargyas from the United States Department of Defense in Washington}

Fax

Dr. Gabor Vargyas

Dept. of Ethnography

Hungarian Academy of Sciences

Janus Pannonius University

Phone (361) 1375-9639

Fax (361) 1375-9639
Date: 11 April 2000

Dave Rosenau

Defence POW-MIA Office

Current Operations Center

Phone (703) 602-2202 Ext.253

Fax (703) 602-1891

(The number 1 in the telephone number is crossed out by hand and replaced with 3 ).

Dr. Vargyas

My name is Dave Rosenau. I am an analyst in the United States Defence Department's Prisoner of War/Missing Personnel Office (DPMO) in Washington, D.C. DPMO oversees the United States' effort to account for Americans lost in service to their nation. During a recent investigation in Vietnam, we met a former associate of yours, Mr. Ho Van Nghe, who suggested we contact you for any information you may have on the subject. Over the past few years, we have received a number of photographs from the area you worked in Vietnam, and we would like your assistance in identifying witnesses, views with regard to the photos, and any other pertinent observations you may have.

We are very interested in meeting with you to discuss this matter. In particular, we would like to show you several photos and obtain your input with regard to when and where they were taken, who took the photos, and the identities of all individuals shown. We would also be interested in viewing any photographs you took during your time in Southeast Asia.

One of our analysts will be in Europe later this month and a brief stop in Budapest could easily be arranged on April $29^{\text {th }}$. Are you amenable to such a meeting? Please respond quickly so final details can be arranged. I can be reached as follows:

Telephone: (703) 602-2202 Ext.253

FAX: (703) 602-1891

E-Mail: rosenaud@osd.pentagon.mil

Respectfully

Dave R 


\section{Document 2: Reply from Gábor Vargyas}

Attention: Mr Dave Rosenau

16 April 2000

United States Defence Department

POW - MIA Office

Current Operations Center

Fax: (703) 602-1891

\section{Mr Rosenau,}

Thank you for your letter of 11 April, 2000 and for your interest in my work.

As a matter of fact I was very much surprised to hear about Mr Ho Van Nghe and his suggestion I could be of any help to you. I arrived to the area 10 years after the war has ended and during my one and a half years of fieldwork in the Khe Sanh area between 1985-1989 I have never seen, met or heard of any prisoner of war, missing people, camp, let alone grave of American soldiers. This is why I think, unfortunately, our meeting is unnecessary.

As you may know, I am an anthropologist, especially interested in religious matters. I worked on shamanism, healing, agricultural rituals and the like. I even made a 42 minutes film on a shamanic ceremony that was passed on the Hungarian TV years ago. If you think it may be of any help, I could send you a copy of it (though it is in Hungarian) just as my scientific publications about Bru - Vân Kiều religion (which are in English or French).

I hope this will help you in your unselfish work.

Respectfully yours

Gábor Vargyas, $\mathrm{PhD}$.

P.S. Please note that the heading of your fax mixes three different addresses of mine. I work at the Institute of Ethnology of the Hungarian Academy of Sciences (Budapest); I have a part time teaching job as Associate Professor at the Janus Pannonius University of Pécs; and the fax number you used is my private home number. I enclose my name card for the sake of clarity. 


\section{Document 3}

National League of Families of American Prisoners and Missing in Southeast Asia http://www.pow-miafamilies.org/about-the-league/

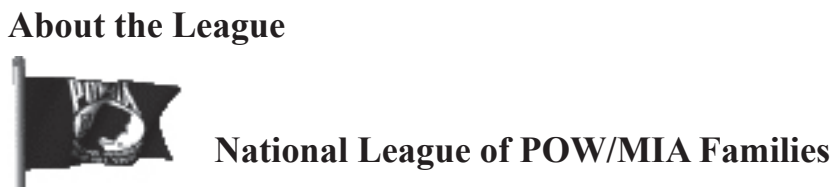

5673 Columbia Pike

Suite 100

Falls Church, VA 22041

703-465-7432

The National League of Families of American Prisoners and Missing in Southeast Asia was incorporated in the District of Columbia on May 28, 1970. Voting membership is comprised of wives, children, parents, siblings and other close blood and legal relatives of Americans who were or are listed as Prisoners of War (POW), Missing in Action (MIA), Killed in Action/Body not Recovered (KIA/BNR) and returned American Vietnam War POWs. Associate membership is comprised of veterans, other concerned citizens and extended family member POW/MIA and KIA/BNR relatives who do not meet voting membership requirements. As a non-profit, tax-exempt, 501(c) 3 humanitarian organization (FEIN \#23-7071242), the League is financed by donations from the families, veterans and others. The League's sole mission is to obtain the release of all prisoners, the fullest possible accounting for the missing and repatriation of all recoverable remains of those who died serving our nation during the Vietnam War.

The League originated on the west coast in the late 1960s. Believing US Government policy of maintaining a low profile on the POW/MIA issue - while urging family members to refrain from publicly discussing the problem - was unjustified, the wife of a ranking POW initiated a loosely organized movement that evolved into the National League of POW/MIA Families. In October 1968, the first POW/MIA story was published. As a result of that publicity, the families began communicating with each other, and the group grew in strength from 50 to 100, to 300, and kept growing. Small POW/MIA family member groups, supported by concerned Americans, met with the North Vietnamese delegation in Paris, and countless thousands of Americans flooded them with telegraphic inquiries regarding the prisoners and missing, the first major activities in which there was widespread public participation.

Eventually, the necessity for formal incorporation was recognized. In May 1970, a special ad hoc meeting of the families was held at Constitution Hall in Washington, DC, at which time the League's charter and by-laws were adopted. Elected by the voting membership, now numbering approximately 1,000, a seven-member Board of Directors meets regularly to determine League policy and direction. Board Members, Regional Coordinators, responsible for activities in multi-state areas, and State Coordinators represent the League in most states. 
The League's national office is directed by the Chairman of the Board and staffed by only one full-time employee, Office Administrator Leslie Swindells, and two part-time archival document specialists. Concerned citizens, family members and universitylevel interns provide support, when available. All participate in implementing policies established by the membership and elected Board of Directors, as well as advocating and coordinating public awareness and education projects. Chairman of the Board and principal League spokesman, Ann Mills-Griffiths, MIA sister, League Executive Director from mid-1978 until mid-2011, continues her role as Chief Executive Officer. For additional information on League policies, positions and activities, check the web site: www.pow-miafamilies.org. The League is nationally eligible for donations through the Combined Federal Campaign (CFC \#10218) and United Way.

Interns: If you are interested in an internship opportunity with the League, please email your resume to: leslie.swindells@pow-miafamilies.org

Gábor Vargyas is scientific councillor at the Institute of Ethnology of the RCH of the Hungarian Academy of Sciences, Budapest, and Professor at the Department of European Ethnology - Cultural Anthropology at the University of Pécs, heading the Doctoral Program. He specializes in the peoples and cultures of Southeast-Asia and Oceania with special interest in religion, ethno-history, culture change, material culture and tribal art. Besides shorter field trips to Australia and Papua New Guinea (1981-82), Congo (Brazzaville) and Angola (1987), Korea (1991), Irian Jaya (1993), Laos (1996), and China (1999), he conducted extensive long-term ethnographic fieldwork among the Bru in the Central Vietnamese Highlands (1985-1989 and 2006-2007). He is the author of, among others, A la recherche des Brou perdus (2000) and a number of articles dealing with different aspects of Bru culture. E-mail: mpaqtoan2@gmail.com 